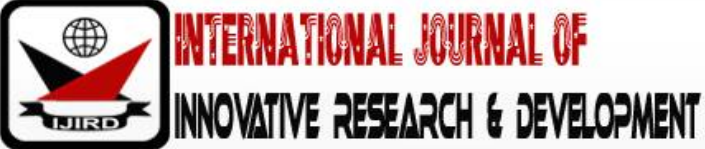

ISSN 2278 - 0211 (Online)

\section{Human Capital Development and Organizational Performance: A Conceptual Review}

\author{
Daniel A.K. Ameyaw \\ Ph.D. Student, Department of Commerce, Adventist University of the Philippines, \\ Puting Kahoy, Silang, Cavite, Philippines \\ Williams Kwasi Peprah \\ Lecturer, School of Business, Valley View University, Oyibi, Accra, Ghana \\ Isaac Anow uo \\ Ph.D. Student, Department of Commerce, Adventist University of the Philippines, \\ Puting Kahoy, Silang, Cavite, Philippines
}

\begin{abstract}
:
The business environment within which organizations compete is becoming more hyper-competitive given fast technological advancement and globalization. Organizations need to create and sustain competitive advantages to survive. Organizations that thrive are those that can create capabilities and competencies that are hard to come by, difficult to imitate, nonsubstitutable and able to create substantial value for their clientele. The attainment of such a feat requires the systematic development of its human capital as it represents the most dynamic resource among all the resources owned by the organization. Developed human capital creates value and generates revenue, able to spot opportunities and take advantage of them, able to develop and implement strategies that make the organization a market leader, and ultimately optimizes organizational performance. Human capital consists of knowledge, skill, and experience. Human development is achieved through coaching, training, and development, empowerment, delegation, and participation.
\end{abstract}

Keywords: Human capital development, human capital, organizational performance, human development

\section{Introduction}

Organizational performance has been the ultimate target for corporate managers over the years as it serves as a yardstick for assessing their individual and organizational performance and also useful for shareholders to assess the performance of the entity. Peprah and Ganu (2018) postulate that human capital affects organizational culture, structure and impact positively on organizational sustainability.

This paper follows that school of thought that, irrespective of the uncontrolled nature of external forces, a competently managed organizational climate evidenced by the developed nature of its human capital can still sail organizations through unconformable external environmental forces into success (Alika \&Aibieyi, 2014). This paper, therefore, focuses on examining how human capital development should be considered as the most vital process required to optimize organizational performance.

\section{Organizational Performance}

Organizational performance is the outcome of the interplay of firms' resources, structure, culture, and environment (Combs, Ketchen, Crook \&Shook, 2005) as Organizational performance could be assessed using financial indicators and non-financial indicators. Some common financial performance indicators are the profitability, return on assets, high sales figures, (Selvarajan et al., 2007; Hsu et al., 2007). Others also include return on investment (ROI), earnings per share (EPS) and net income after tax (NIAT) (Grossman, 2000).

Additionally, organizational performance is assessed by benchmarking financial indicators against managerial accounting indicators. The non-financial indicators are generated using the perceived performance approach (Marimuthu, Arokiasamy, Ismail, 2009) which requires subjective performance assertions to be placed in the form of statements while responses (usually on a Likert scale) are required to indicate the extent to which those statements reflect the perception of top management relative to organizational performance (Selvarajan et al., 2007).

The most critical resource of every organization is its human capital. It provides the dynamic, responsive and creative force required to achieve and sustain the competitive advantage desired most by organizations. The human capital and its development are critical to ensuring the maintenance and improvement of the performance of any organization (Ostroff \& Bowen, 2000). Human capital in organizations is the knowledge, skill, and experience of employees (Peprah, \& Ganu, 2018)inand organization that contribute to sustainable competitive advantage. 
Due to this, human capital development has become critical and plays a crucial role in ensuring the improvement in organizational performance (Boselie \& Paauwe, 2005; Ostroff \& Bowen, 2004). Several studies have therefore found some positive relationship between human functions of resource management and organizational performance (Klein \& Kozlowski, 2000; Schuler \& Jackson, 1995; Ostroff \& Bowen, 2004).

The human resource management functions are many,yet human capital development in this paper is deemed as one worthy of focus. This is because of the assertion that, an organization with all other resources inadequate forms may miss the market leadership spot if its human capital is inappropriately developed to spot opportunities, create strategies, implement those strategies to gain competitive advantage and sustain that competitive advantages (Peprah \& Ganu, 2018). This requires a detailed historical examination of the concept of human capital and the aspects of it that should be developed. Also, what forms should such developments take and how could human capital development be used as a catalyst for sustained organizational performance?

\section{Conceptualizing Human Capital Development (HCD)}

The HCD is a three syllabi concept that would be split into two; human-capital (one phrase) and development. The quantum or manner in which human beings can generate and use knowledge and skill toward creating intellectual capital is broadly referred to as human capital (Armstrong, 2006). Thus, the higher a person's ability to create more relevant intellectual capital, the higher he or she is considered as of higher human capital.

The acquisition of this 'relevant' knowledge is the product of conscious and unconscious interactions between them and other human beings which is often referred to as social capital which facilitates the generation of critical and well entrenched institutionalized knowledge possessed by an organization (organizational capital). Thus, human capital as a concept requires a discussion of other terminologies like the human, intellect, social capital and organizational capital (Armstrong, 2006).

Whiles intellectual capital refers to the intangible resources associated with people that enable them to effectively utilize tangible resource (money and physical assets) towards creating value for the organization (Bontis, 1996), social capital is the conscious relationship and norms that shape the quality and quantity of a society's social interaction (Putnam, 1996 and World Bank 2000).

The originator of 'human-capital' as a coined word is Schultz (1961) who primarily referred to that concept as abilities of the human being useful to an organization. His emphasis was on how the human being can use his or her abilities right time, form and approach to help an organization to achieve its goals.

In a later paper in 1981, Schultz detailed the concept further by stating that human capital refers to all human abilities either innate or acquired that consist of attributes which are valuable and can be augmented by appropriate investment. This definition, though a formidable one at its initial evolution stage, lacked other specifics that would make survive foreverregarding its relevance to changing dynamics of the human resource management practice and literature.

As a result, some researchers over time attempted to conceptualize human-capital further. Bontis, Dragonnetti, Jacobsen, and Roos (1999) for instance defined human capital as the human factor in the organization consisting of combined intelligence, skills, and expertise that gives the organization its distinctive character. They explained that these human elements of the organization possess the capability of learning, changing, innovating and creativity that when properly motivated can ensure the long-term survival of the organization.

A careful look at the definition of Bontis et al. (1999) reveals some features that make it superior to that initial one presented by Schultz on two scores. Bontis et al. (1999) were able to emphasize the dynamic nature of human capital by stating that it possesses the ability to learn, change, innovate and create. These characteristics of human capital have made it most indispensable among all other resources of an organization such that irrespective of the level of technological advancement of recent times, the human capital element of organizations have still been found to be irreplaceable. Also, the definition of Bontis et al. (1999) underscored the critical role of management in providing the necessary leadership towards making the right investments that enable the human capital to relevantly function towards the goals and aspirations of the organization in question.

Further review of literature also exposed other interesting definitions that present other important twits that are silenced in the earlier ones discussed. Scarborough and Elias (2002) for instance believe that 'human capital' as a concept should be first viewed as a conduit that provides the right link between human resource practices for the business performance regarding assets rather than business processes.Thus, human capital is mostly dynamic, context-dependent, non-standardized, tacit and subjectively embodied in people. The elements of flexibility, responsiveness, and dynamism explain the value of human capital.

It is clear that human capital is not the individual but the traits, skills, and knowledge that the individual possesses that makes up the capital. These traits can also be molded into a form that can contribute towards the growth of organizations, thereby highlighting the critical importance of other human capital management concepts like recruitment, training, development, employee appraisal, and motivation towards ensuring that the human capital can create the highest value for the organization in question.

\section{Human Capital Theory}

The fundamental claim of this principle is that human capital is the added value that people bring to an organization (Armstrong, 2006). Human capital is now an asset to any organization.

The human capital theory is therefore primarily positioned on the Resource-Based View (RBV) model of a firm which was initially propounded by Barney (1991). The theory, therefore, requires organizations' competitive advantage to be the direct function of its human capital depending on how valuable it is, how rare it is, how inimitable it is and how non- 
substitutable it is. Thus, the more human capital passes this litmus test of a framework, the more it is considered as of critical importance.

Other authors like Coff (1997) for instance view human capital theory to suggest that employees possess skills, knowledge, and abilities that have the potential of generating economic rent. Economic rent is the profits more than formal economic returns.

In that regard, human capital could transform into a human capital advantage (Boxall, 1996) when it emanates from employing people with competitively valuable knowledge and tacit skills that are very difficult to copy. This should, therefore, be one of the targets of corporate managers to ensure that their human capital facilitates the necessary advantages through value creation that it desires most.

Armstrong (2006) however differentiate between human capital advantage and human process advantage in the sense that, the latter is entrenched when inimitable, the high evolving process is instituted within a firm. Therefore, the ultimate attainment of competitive advantage at the corporate level is a function of human capital advantages and human process advantages.

As such, the human capital theory could be conceptualized in the diagram below (Figure 1). In the diagram, it is observed that human capital which is considered aneffectivetoachieving the goals of an organization would be the direct function of

- Well instituted inimitable, high evolving process

- Rare Skill, knowledge, and abilities

- Capabilities that produces the highest value to key stakeholders of the organization

- Difficult to imitate Skill, knowledge, and abilities

\section{Human Development}

The second syllabus in the human capital development concept is the element of "development." To develop the means to make or become more mature, more advanced, more complete, more organized and more detailed. Thus, the term develop connotes an improvement on a previous state. This improvement should, however, be conceived from the point of the aspired position of that entity.

The development aspect of 'human capital development concept' would, therefore, require the enhancing of the human capital into a form that is more desired by an organization. In most human resource management literature, human capital development has been used synonymously to human resource development. In which case it refers to the identification of needed skills and the corresponding active management of learning in line with the corporate and business strategy of an organization (Armstrong, 2006; Harrison, 2005)

Thus, human capital development could be further categorized into two based on the time horizons. These are tactical human capital development and strategic human resource development. Whereas the former focuses on meeting short-term business and corporate strategy objectives, the latter focuses on meeting long-range future corporate and business strategy objectives of organizations.

Armstrong (2006) therefore posits that development of human capital will require a combination of organizational learning strategies, strategies to enhance individual learning, effective execution of training workshops and formal off-the-job training as well as blended strategies consisting of all these. At this stage, the paper wishes to center on the development and not just training of human capital (though in most human resource management literature they are used jointly; see Armstrong 2006; Harrison, 2005). Thus, training, according to Cole (2002), is a learning activity is the acquisition of specific knowledge and skills to perform a task. Training is given to employees to be efficient and effective on the jobs or roles.

Development is the process used to build the capacity of the employees to achieve and sustain goals and desires to the benefit of the employee, firm, community and the world.(Garavan, Morley, Gunnigle \& Collins 2001). In their view, development requires the evaluation of the organization's current environment - external and internal - and aiding people, teams, and the organization to identify and develop strategies that improve performance. Where the evaluation process brings out an issue or problem that requires attention or needs to be solved, the development process will seek to generate ideas and solutions that address the problem and can effectively return the unit to a state of high performance. However, if no negatives are resulting from the evaluation, then the development process will seek ways of developing and enhancing existing relationships and performances. To this end, development can denote creating and sustain change and performance (Marimuthu et al. 2009).

Human capital development is, therefore, becoming an increasingly critical and strategic imperative for organizations in the current business environment (Sheri-lynne \& Parbudyal, 2007). The following five variables of human capital development according to (Sheri-lynne \& Parbudyal, 2007) are more likely to affect employee performance. These include coaching, training, and development, empowerment, participation, and delegation.

- Coaching: Is an intervention that seeks to bring an employee to his predetermined performance level in his current function within an organization. It is guided, structured and requires continues monitoring (Colomo \& Casado, 2006). The organization appoints a coach for the employee with the aim that, the coach will work with the employee to correct work-related defects and improve employee skills, knowledge and abilities to enhance performance. Individuals are allowed to take responsibility and are treated as partners (Agarwal, Angst \& Magni. 2006).

- Training and Development: Training and development is an activity aimed at imparting to employees the requisite skills, knowledge, and behaviors necessary for their jobs (Keys \& Wolfe, 1988). Training is task related as it provides operational and technical employees with the specific knowledge and skills required for the completion 
of their assigned tasks (Cole, 2005; Griffin, 2002). Development, on the other hand, is futuristic as it seeks to prepare employees for growth in their careers rather than immediate performance. It involves developing the abilities and potential through learning experiences (Cole, 2005). Training is the permanent change in behavior with employees being taught how to do a particular task whiles development is a long-term process (Leibowitz, 1981).

- Empowerment: Developing human capital through empowerment involves the transfer of responsibility and operational management from line managers to operational teams and individuals (Kamal et al. 2008). It increases the capacity of the employee and also provides freedom of work which builds the confidence among the employees (Sheri-lynne \& Parbudyal, 2007) and motivates them to work harder thereby enhancing the individual and organization's performance. Empowering employees enhances their ability to take initiatives (Frese, Kring, Soose, \& Zempel, 1996), be proactivity (Parker, Williams, \& Turner, 2006), reduces the costs of supervision and other indirect costs (Batt, 2001; Parker \& Wall, 1998), and provides the opportunity for individuals to develop and use new knowledge and skills (Leach, Wall, \&Jackson, 2003).

- Participation: The involvement of employees in firms decision-making and policies creation can lead the workers to enhance the performance.

- Delegation: If managers delegate authority to the employees to perform the task, what they want can also lead to enhancing performance. It will lead to achieving organizational goals and thus enhance organizational performance.

Relatedly, Harrison (2005) asserts that organizations are required to set their priorities when developing their human capital. In his view, the following steps should be following should be followed in setting priorities for human capital development;

- $\quad$ Raise awareness of the need for a learning culture that leads to continuous improvement

- Develop the competence of managers to become actively involved in learning that leads to knowledge creation.

- Expand learning capacity throughout the organization

- Focus on all the organization's knowledge workers, not just the critical personnel

- Harness e-learning to knowledge sharing and creation.

\section{Human Capital Development Impact on Organizational Performance}

The impact of human capital on organizational performanceis discussed from the individual and organizational perspectives as these two forms the essential components of human capital (Marimuthu et al., 2009). According to Garavan et al., (2001), there are four attributes of human capital - flexibility and adaptability; enhancement of individual competencies; development of organizational competencies; and individual employability- that create value and enhances individual and organizational outcomes.

Fatoki (2011) posits that organizations with higher general and specific human capital qualities regardingthe relevance of knowledge, skill,and abilities to the industry of an organization can be expected to show higher levels of performance than those with lower levels of such general and specific human capital qualities.

Michael and Zaid (2014) investigated the influence of human capital development on organizational performance in the Nigerian banking sector in the state of Osun. The study established thatthe Nigerian financial sector employees are knowledgeable, skilled, competence.The research resulted that there is a significant relationship between human capital development and organizational performance.

Awan \& Sarfraz (2013) studied the impact of human capital on the performance of firms with the intervening effect of employee's job satisfaction. It considered a sample of 3 firms. The study revealed that there exists a strong positive relationship between human capital and firm performance. The paper found that human capital is the most valuable, inimitable, rare and non-substitutional assetofany organization. It helps the firm to grow and achieve its objectives more effectively and efficiently. It also shows that education, training, and skills influence the company performance in any way.

Also, Seleim, Ashour,and Bontis (2007) studied the relationship between human capital and organizational performance in the software industry in Egypt. The study revealed that training and teamwork practices turned employees into superstar performers and their increased productivity enhanced organizational performances. They concluded that human capital indicators had a positive relationship with organizational performance.

Marimuthu et al. (2009) conducted a study on human capital development and its impact on firm performance with evidence from developmental economics. The study concluded that the infusion of human capital enhancement elements in organizations promotes innovativeness and higher performance.

There is no doubt that human capital development is a critical element required for the growth of an organization such that it is traceable to the financial and financial performance of an organization. 


\section{Research Paradigm}

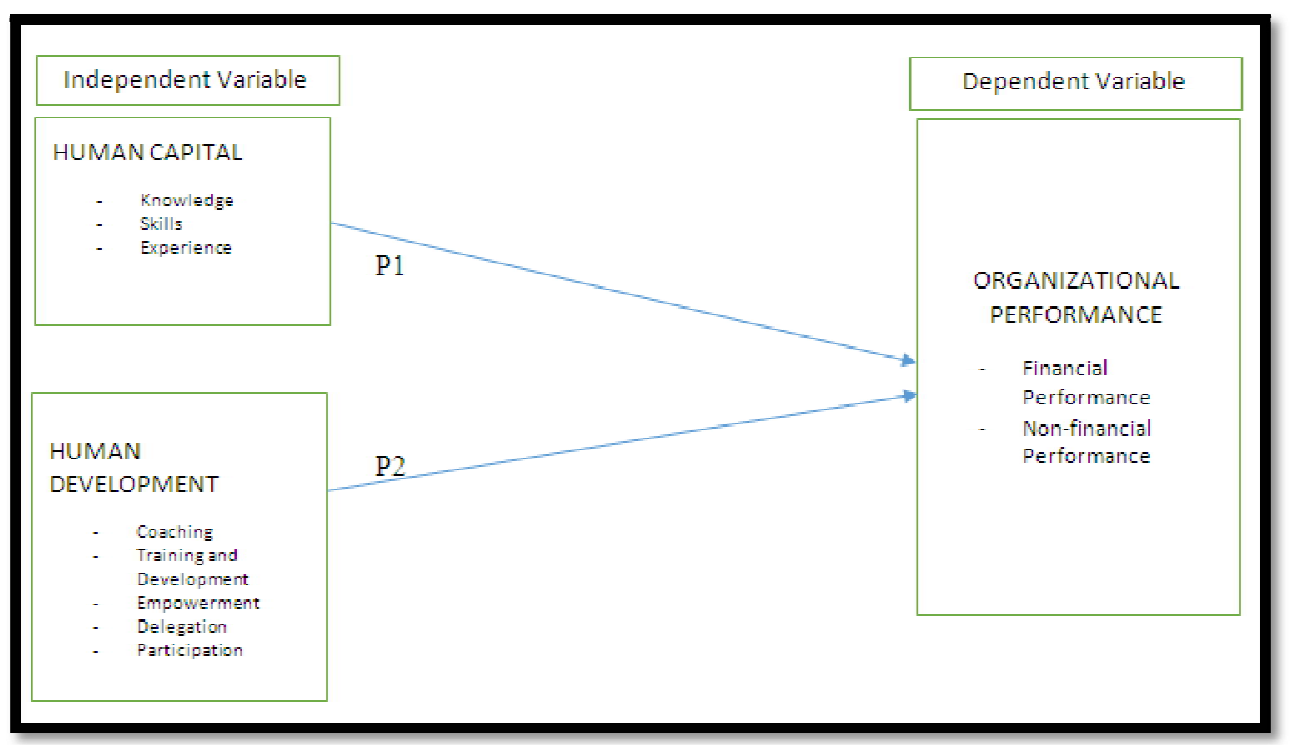

Figure 1

The research paradigm portrays how to solve the problem of organizational performance with the solutionsto human capital and human development. Based on the discussion above the following hypothesis can be deduced:

- P1:There is no significant relationship between Human Capital and Organizational Performance.

- P2: There is no significant relationship between Human Development and Organizational Performance

This study recommends that future research must be done to test the empirical result to confirm this conceptual analysis.

\section{Conclusion}

Human capital development is indeed a vital element required to achieve sustained higher performance in any organization. The human capital of an organization is so dynamic that when well developed it does not suffer obsolesce, redundancy or irrelevance. Rather it can engineer human process advantages and human capital advantages that propel increased productivity among employees, enhance strong client relationship the generate loyalty to the brand of that organization leading to a sustained increase in revenues which translates positively in Return on Assets, Return on Investment and positive perception among the clientele of the organization.

Indeed, human capital development plays a significant role in securing the attainment of the organization's objectives; hence associated investment in human capital benefits all stakeholders of the organization. To make the process more effective, it should be performance-related- designed to achieve specified improvements in the corporate, functional, team and individual performance towards influencing the bottom-line results.

\section{References}

i. Agarwal, R., Angst, C.M., \& Magni, M. (2006). The performance effects of coaching: A multilevel analysis using hierarchical linearmodelling. Robert H. Smith School of Business Research Paper Series

ii. Alika, I. J. \& Aibieyi, S. (2014). Human Capital: Definitions, Approaches and Management Dynamics. Journal of Business Administration and Education, 5(1), 55-78.

iii. Armstrong, M. (2006). Human Resource Management Practice (10th ed). Kogan Page. London and Philadelphia.

iv. Awan M.A.S.A. \& Sarfraz N. (2013). The impact of human capital on company performance and the mediating effect of employee satisfaction. IOSR Journal of Business and Management, Vol. 8 (2), pp 76- 82

v. Barney, J.B. (1991). Firm resources and sustained competitive advantage, Journal of Management, Vol.17 (1) pp. 99-120

vi. Batt R. (2001). The economics of teams amongst technicians, British Journal of Industrial Relations, Vol. 39, 1-4

vii. Bontis, N. (1996). There's a price on your head: Managing Intellectual Capital Strategically, Business Quarterly. Summer, pp. 4-47

viii. Bontis, N., Dragonetti, N., Jacobsen, K. and G. Roos. (1999). "The knowledge toolbox: A review of the tools available to measure and manage intangible resources", European Management Journal. Vol. 17, Iss. 4, pp. 391-402

ix. Boselie, P., \& Paauwe, J., (2005). HRM and performance: What next? Human Resource Management Journal. Vol.15, pp. 68-83

x. Boxall, P. (1996). The strategic HRM debate and the resource based view of the firm, Human Resource Management Journal, Vol. 6 (3), pp. 59-75.

xi. Coff, R.W., (2007). Human Assets and Management Dilemmas: Coping with Hazards on the road toResource Based Theory. Academy of Management Review. Vol. 22: 374-402

xii. Cole, G. A. (2002), Personnel and Human Resource Management, $\left(5^{\text {th }}\right.$ ed). Continuum London: York Publishers

xiii. Cole, G. A (2005) Personnel and Human Resource Management, 5th Edition, Padstow Cornwall T.J International 
xiv. Colomo, R., \& Casado, C. (2006). Mentoring and Coaching. Its perspective. Journal of Technology Management and Innovation. Vol. 3: 131-139

xv. Combs J. G., Ketchen D. J., Crook T. R. \& Shook C. L. (2005). The dimensionality of organizational performance and its implications for strategic management research. In Ketchen D. J. (Ed.), Research methodology in strategy and management, 2, 259-286

xvi. Fatoki, O.O (2011). The Impact of Human, Social and Financial Capital on the Performance of Small and MediumSized Enterprises (SMES) In South Africa.Journal of Social Sciences, Vol. 29(3); pp. 193-204.

xvii. Frese, M., Kring, W., Soose, A., \& Zempel J. (1996). Personal initiative at work: Differences between East and West Germany. Academy of Management Journal Vol. 39, pp. 37-63.

xviii. Garavan, T. N., Morley, M., Gunnigle, P., \& Collins, E. (2001). Human Capital Accumulation: The role of human resource development. Journal of European Industrial Training. 25(2/3/4), 48-68.

xix. Griffin, R. W (2002) Management, 7th Edition, USA, Houghton Mifflin Company

xx. Grossman, R. J. (2000). Measuring up: Appropriate metrics help HR prove its worth. HR Magazine. Vol. 45(1), 2835.

xxi. Harrison, R. (2005). Learning and Development. CIPD Publishing.

xxii. Hsu, I. C., Lin, C.Y.Y., Lawler, J.J., \& Wu, S.H. (2007). Toward a model of organizational human capital development: Preliminary evidence from Taiwan. Asia Pacific Business Review, 13(2), 251-275.

xxiii. Kamal, B., Clegg, C., Patterson, M., Robinson, A., Stride, C.B., Wall, T.D., \& Wood, S.J. (2008). The Impact of Human Resource and Operational Management Practices on Company Productivity: A longitudinal study: Personnel Psychology.

xxiv. Keys, B. and Wolfe, J. (1988), Management Education and Development: Current Issues and Emerging Trends, Journal of Management, Vol 14, pp. 205-299

xxv. Klein, K. \& Kozlowski, A. (2000). Investigating the Use of Human Resource Management Best Practice in New Zealand Firms. Ota. Management Review Journal, 2:39-68.

xxvi. Leach, D.J., Wall, T.D., \& Jackson, P.R. (2003). The effect of empowerment on job knowledge: An empirical test involving operators of complex technology. Journal of Occupational and Organizational Psychology, 76, 27-52.

xxvii. Leibowitz, Z. and Schlossberg, N. (1981). 'Training managers for their role in a career development system',Training and Development Journal, p 72-79

xxviii. Marimuthu, M, Arokiasamy \& Maimunah I. (2009). Human capital development and its impact on firm performance: evidence from developmental economics, The Journal of International Social Research,2(8); 265272

xxix. Michael, O.O., \& Zaid, A.A. (2014). An Empirical Analysis of Human Capital Development and Organizational Performance in Banking Sector: A Nigerian Experience.International Journal of Economics, Commerce and Management. Vol 2, Issue 7.

xxx. Ostroff, C. \& Bowen, D. E. (2004). Understanding HRM-firm performance linkages: The role of the "strength" of the HRM system. Academy of Management Review, 29(2), 203-221.

xxxi. Ostroff, C. \& Bowen, D. (2000). Moving HR to a higher level: HR practices and organizational effectiveness. In Kozlowski S, Klein K (Eds.), Multilevel theory, research and methods in organizations (pp. 211-266). San Francisco: Jossey-Bass.

xxxii. Parker, S.K., \& Wall, T.D. (1998). Job and work design. London: Sage

xxxiii. Parker, S.K., Williams, H., \&Turner, N. (2006). Modelling the antecedents of proactive behavior at work. Journal of Applied Psychology, 91, 636-652.

xxxiv. Peprah, W. K., \& Ganu, J. (2018). The convergence of organizational culture, structure and human capital performance: A conceptual analysis. Archives of Business Research, 6(5), 212-221. DOI:10.14738/ abr.65.4626.

xxxv. Scarborough, H. and Elias, J. (2002) Evaluating Human Capital, London, CIPD

xxxvi. Schuler, R.S., \& Jackson, S.E. (1995). Understanding Human Resource Management in the context of Organizations and their Environment. Annual Review of Psychology. 46, 237-264.

xxxvii. Schultz, T. W. (1961) Investment in Human Capital, American Economic Review, Vol. 51, pp.1-17

xxxviii. Schultz, T.W. (1993). The economic importance of human capital in modernization. Education Economics, 1(1), 13-19.

xxxix. Seleim, A., Ashour, A., \& Bontis, N. (2007). Human capital and organizational performance:

xl. A study of Egyptian software companies. Management Decision. 45(4), 789-801.

xli. Selvarajan, T. T., Ramamoorthy, N., Flood, P. C., Guthrie, J. P., MacCurtain, S., \& Liu, W. (2007). The role of human capital philosophy in promoting firm innovativeness and performance: Test of a causal model. International Journal of Human Resource Management, 18(8), 1456-1470.

xlii. Sheri-Lynne, L. \& Parbudyal S. (2007). Leadership development: learning from best practices. Leadership and Organization Development Journal, 28 (5) 